\title{
Astylus variegatus (Coleoptera, Melyridae): Cytogenetic study of a population exposed to agrochemical products
}

\author{
Marielle Cristina Schneider ${ }^{1}$, Bianca Pierina Carraro ${ }^{2}$, Doralice Maria Cella ${ }^{1}$, Rodrigo \\ Rodrigues Matiello ${ }^{3}$, Roberto Ferreira Artoni ${ }^{2}$ and Mara Cristina Almeida ${ }^{2}$ \\ ${ }^{1}$ Departamento de Biologia, Instituto de Biociências, Universidade Estadual Paulista, \\ Rio Claro, São Paulo, Brazil. \\ ${ }^{2}$ Departamento de Biologia Estrutural, Molecular e Genética, Universidade Estadual de Ponta Grossa, \\ Ponta Grossa, Paraná, Brazil. \\ ${ }^{3}$ Departamento de Fitotecnia e Fitossanidade, Universidade Estadual de Ponta Grossa, Ponta Grossa, \\ Paraná, Brazil.
}

\begin{abstract}
In this work we describe the cytogenetic analyses performed in specimens of Astylus variegatus (Germar, 1824) collected in two localities: one area of natural vegetation and one of agricultural crops, where agrochemical products were used. Astylus variegatus had karyotypes with $2 \mathrm{n}(\mathrm{male})=16+\mathrm{Xy}_{\mathrm{p}}$ and $2 \mathrm{n}$ (female) $=16+\mathrm{XX}_{\mathrm{p}}$, with exclusively metacentric chromosomes. Pachytene spermatocytes showed synapsed autosomal bivalents and non-associated sex chromosomes. In diplotene, the autosomal bivalents exhibited one or two terminal chiasmata and the $\mathrm{Xy}_{\mathrm{p}}$ had a typical parachute configuration. In meiotic cells of some specimens, an extra chromosome, interpreted as a B chromosome, was observed. C-banding showed constitutive heterochromatin in the pericentromeric region of all chromosomes, with the exception of the $y_{p}$. Silver nitrate staining revealed one nucleolus organizer region (NOR) on the terminal region of the short arm of the second autosome pair. Silver staining of meiotic cells confirmed the NOR pattern detected in mitotic cells and revealed an argentophilous material on the $\mathrm{Xy}_{\mathrm{p}}$. A cytogenetic comparison between the two populations of $A$. variegatus showed a statistically significant divergence $\left(\chi^{2}=117.10\right.$; $\left.\mathrm{df}=1\right)$ in the number of aneuploid cells and a higher frequency of $B$ chromosome in the population exposed to agrochemicals.
\end{abstract}

Key words: B chromosome, constitutive heterochromatin, karyotype, meiosis, Ag-NORs.

Received: September 19, 2006; Accepted: January 22, 2007.

\section{Introduction}

Astylus variegatus is endemic to the Neotropical region and belongs to the superfamily Cleroidea (Lawrence and Newton, 1995). This superfamily comprises around 10.000 species included in eight families (Lawrence and Newton, 1995; Costa, 2003). Cytogenetic data, however, are restricted to 15 Cleroidea species of two families, Cleridae and Melyridae (Smith and Virkki, 1978; Yadav and Dange, 1989).

All the 12 species of the family Cleridae previously studied had the same diploid number $(2 \mathrm{n}=18)$ and a sex chromosome system of the $\mathrm{Xy}$ type. In this system, the $\mathrm{X}$ and the y represent the sex chromosomes and the "p" indicates the meiotic configuration of the sex chromosomes,

Send correspondence to Marielle Cristina Schneider. Departamento de Biologia, Instituto de Biociências, Universidade Estadual Paulista, Av. 24-A, 1515, Caixa Postal 199, 13506-900 Rio Claro, SP, Brazil. E-mail: maricb@rc.unesp.br. which was compared to a parachute by Stevens (1906). The chromosome morphology has been reported for six Cleridae species: Enoclerus sp., Necrobia ruficollis, Necrobia rufipes, Priocera spinosa, Thanasimus formicarius, and Trichodes apiarius. All these species presented exclusively meta/submetacentric chromosomes (Virkki, 1960, 1963; Smith and Virkki, 1978; Yadav and Dange, 1989). In contrast, the three studied species of the family Melyridae, which includes A. variegatus, presented different karyotypes: Endeodes collaris showed $2 \mathrm{n}=18+\mathrm{X} 0$, Collops sp. exhibited $2 \mathrm{n}=16+\mathrm{X} 0$, and Hoppingiana hudsonica revealed $2 \mathrm{n}=12+\mathrm{X} \mathrm{y}_{\mathrm{p}}$. The chromosomes morphology has not been described in any of these species (Smith and Virkki, 1978).

Cytogenetic analyses of Cleroidea species are restricted to conventional staining. Therefore, there are no data on specific chromosome regions, such as constitutive heterochromatin and nucleolar organizer regions (NORs), 
for Cleroidea species, which could be useful in understanding the chromosome evolution strategies in the group.

Many beetle species are considered agricultural pests because they feed on cultivated plants or on stored grains. The control of these species is thus economically important. During its larval phase, Astylus variegatus can damage seeds in the soil before they germinate. This species is considered a minor agricultural pest because only a large population is capable of harming some cultivated plants, specially maize (Matioli et al., 1990; Viana et al., 2002). Nevertheless, agrochemical products, such as insecticides, have sporadically been required to control $A$. variegatus populations (Viana et al., 2002).

None of the species of Brazilian Melyridae has been cytogenetically analyzed and $A$. variegatus specimens are found on cultivated plants and consequently exposed to agrochemical products. In this work, we performed a cytogenetic study of $A$. variegatus, including the description of its karyotype, C-banding, nucleolus organizer regions (NORs) distribution and meiosis. We also analyzed mitotic and meiotic chromosomes of specimens collected on cultivated plants, such as beans, maize, soybean, and sunflower, which have been exposed to agrochemical products.

\section{Material and Methods}

Forty adult specimens of $A$. variegatus were collected in two localities of Ponta Grossa, state of Paraná, Brazil: 20 specimens in an area of natural vegetation (Bairro Sabará $25^{\circ} 04^{\prime} 57^{\prime \prime} \mathrm{S}, 50^{\circ} 12^{\prime} 38^{\prime \prime} \mathrm{W}$ ) and 20 specimens in an agricultural area (Fazenda Escola Capão da Onça - 2505'41" S, $\left.50^{\circ} 03^{\prime} 40^{\prime \prime} \mathrm{W}\right)$ from the Universidade Estadual de Ponta Grossa (Table 1). Chromosome preparations were obtained from gonads of adult male and female specimens. The testes were removed in insect saline solution $(128.3 \mathrm{mM}$ $\mathrm{NaCl}, 16.7 \mathrm{mM} \mathrm{Na}_{2} \mathrm{HPO}_{4}, 19.9 \mathrm{mM} \mathrm{KH}_{2} \mathrm{PO}_{4}$ ), incubated in tap water as an hypotonic treatment for five minutes, and fixed in Carnoy I ( 3 methanol: 1 acetic acid) for $30 \mathrm{~min}$. In order to obtain a large number of mitotic metaphases, some dissected gonads (testes and ovaries) were immersed in a colchicine solution ( $0.05 \%$ in insect saline solution) for two hours before the hypotonic treatment. After fixation, the gonads were macerated in $45 \%$ acetic acid and the slides were dried on a hot plate at $35-40{ }^{\circ} \mathrm{C}$. All chromosome preparations were stained with a $3 \%$ Giemsa solution (94 $\mathrm{mL}$ of distilled water, $3 \mathrm{~mL}$ of Giemsa-Merck, and $3 \mathrm{~mL}$ of phosphate buffer - $\mathrm{pH}$ 6.8) for $15 \mathrm{~min}$. Constitutive heterochromatin and NORs were detected by C-banding (Sumner, 1972) and with silver nitrate (Howell and Black, 1980), respectively. Chromosomes were morphologically classified according to Levan et al. (1964).

The chromosome data of the specimens collected in the two different localities (area of natural vegetation - control population and area of agricultural crops - population exposed to agrochemical products) were compared. A total
Table 1 - Specimens of Astylus variegatus collected in different crops in an agricultural area.

\begin{tabular}{|c|c|c|c|}
\hline $\begin{array}{l}\text { Number of } A \text {. } \\
\text { variegatus speci- } \\
\text { mens collected }\end{array}$ & $\begin{array}{l}\text { Cultivated } \\
\text { plants }\end{array}$ & $\begin{array}{l}\text { Agrochemical } \\
\text { products }\end{array}$ & $\begin{array}{l}\text { Concentration } \\
\text { applied }\end{array}$ \\
\hline 10 & Beans & $\begin{array}{l}{ }^{1} \text { Deltamethrin } \\
{ }^{2} \text { Glyphosate } \\
{ }^{1} \text { Chlorpyriphos } \\
{ }^{2} \text { Imazethapyr }\end{array}$ & $\begin{array}{l}0.50 \mathrm{~L} / \mathrm{ha} \\
2 \mathrm{~L} / \mathrm{ha} \\
0.50 \mathrm{~L} / \mathrm{ha} \\
1 \mathrm{~L} / \mathrm{ha}\end{array}$ \\
\hline 2 & Maize & $\begin{array}{l}{ }^{1} \text { Deltamethrin } \\
{ }^{1} \text { Chlorpyriphos } \\
{ }^{2} \text { Atrazine } \\
{ }^{2} \text { Atrazine }\end{array}$ & $\begin{array}{l}0.20 \mathrm{~L} / \mathrm{ha} \\
0.50 \mathrm{~L} / \mathrm{ha} \\
5 \mathrm{~L} / \mathrm{ha} \\
0.80 \mathrm{~L} / \mathrm{ha}\end{array}$ \\
\hline 4 & Soybean & $\begin{array}{l}{ }^{1} \text { Deltamethrin } \\
{ }^{3} \text { Carbendazim } \\
{ }^{3} \text { Fluquinconazole }\end{array}$ & $\begin{array}{l}0.40 \mathrm{~L} / \mathrm{ha} \\
350 \mathrm{~g} / \mathrm{ha} \\
100 \mathrm{~g} / \mathrm{ha}\end{array}$ \\
\hline 4 & Sunflower & $\begin{array}{l}{ }^{2} \text { Glyphosate } \\
{ }^{2} \text { Clethodim } \\
{ }^{1} \text { Methamidophos }\end{array}$ & $\begin{array}{l}3 \mathrm{~L} / \mathrm{ha} \\
0.40 \mathrm{~L} / \mathrm{ha} \\
0.50 \mathrm{~L} / \mathrm{ha}\end{array}$ \\
\hline
\end{tabular}

1 = insecticide $; 2$ = herbicide; 3 = fungicide .

of 1693 conventionally stained cells per population were analyzed. The significance of the cytogenetic differences observed between the two populations of $A$. variegatus were statistically evaluated by the chi-square test.

\section{Results}

\section{Conventional staining}

Spermatogonial and oogonial metaphases of $A$. variegatus showed $2 \mathrm{n}=18$. The male karyotype consisted of eight homomorphic pairs and two unpaired elements identified as the sex chromosomes, whereas the female karyotype was composed of nine homomorphic pairs, that is, eight autosomal and one sexual pair. The analyses of male meiotic cells and a comparison between the male and female karyotypes revealed a sex chromosome system of the X $y_{p}$ type. All the chromosomes were metacentric. The autosome pairs gradually decreased in size and the $\mathrm{X}_{\mathrm{p}}$ chromosome was slightly smaller than the smallest autosome pair. The $\mathrm{y}_{\mathrm{p}}$ chromosome was a dot-like negative heteropycnotic structure (Figures 1 and $4 \mathrm{~A}$ ).

Positively heteropycnotic material was observed as a block and some dots in interphase testes cells (Figure 2A). These regions probably correspond to the sexual chromatin and heterochromatic regions, respectively. Pachytene spreads showed eight autosomal bivalents regularly synapsed along their entire length and two univalent sex chromosomes (Figures 2B and 5B). One or two terminal chiasmata were observed in the autosomal bivalents during diplotene, while the sex chromosomes were associated in a typical parachute configuration (Figure 2C). Prophase I and metaphase I cells revealed the meioformula $2 \mathrm{n}=8 \mathrm{II}+\mathrm{X} \mathrm{y}_{\mathrm{p}}$, in agreement with the diploid number and sex chromosome system observed in mitotic cells (Figure 2C-D). Metaphase 
II cells showed $n=8+X_{p}$ or $n=8+y_{p}($ Figure $2 E-F)$. The $X_{p}$ and $\mathrm{y}_{\mathrm{p}}$ sex chromosomes were positively and negatively heteropycnotic, respectively, during most of the meiosis.

Specimens of $A$. variegatus collected in the areas of natural vegetation and of agricultural crops showed the

A

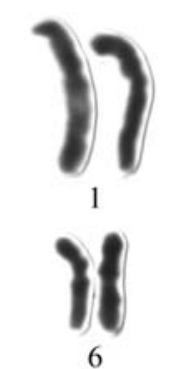

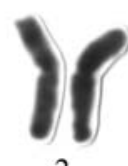

2

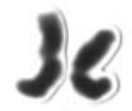

7

B

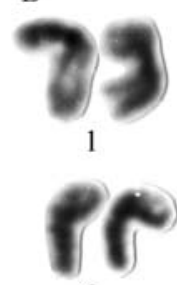

6

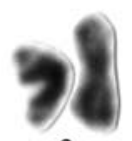

2

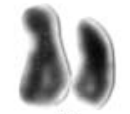

7

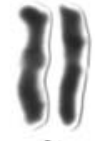

3
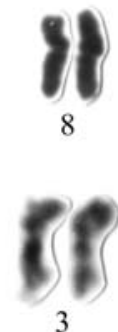

3

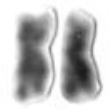

8
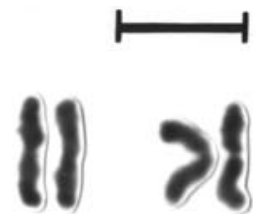

4 5

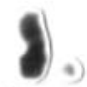

Хр ур
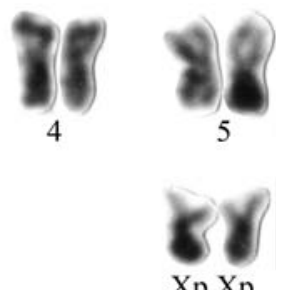

Figure 1 - Karyotypes of Astylus variegatus: A) Male, with $2 \mathrm{n}=16+X \mathrm{y}_{\mathrm{p}}$, note the extremely small $\mathrm{y}_{\mathrm{p}}$ sex chromosome; B) Female, with $2 \mathrm{n}=16+\mathrm{XX}_{\mathrm{p}}$. Scale bar $=5 \mu \mathrm{m}$.

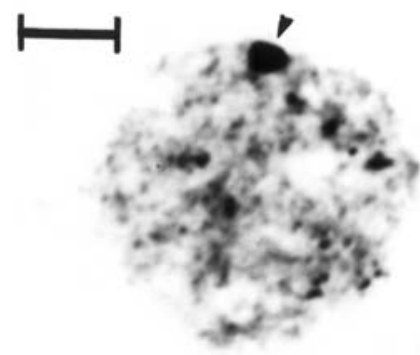

A

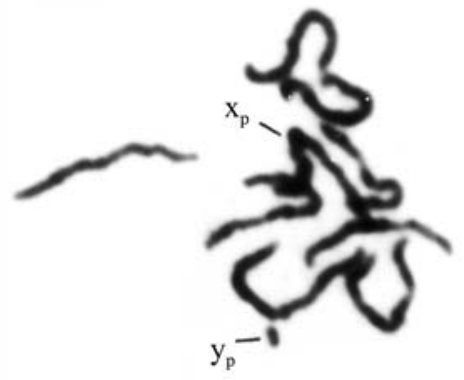

B
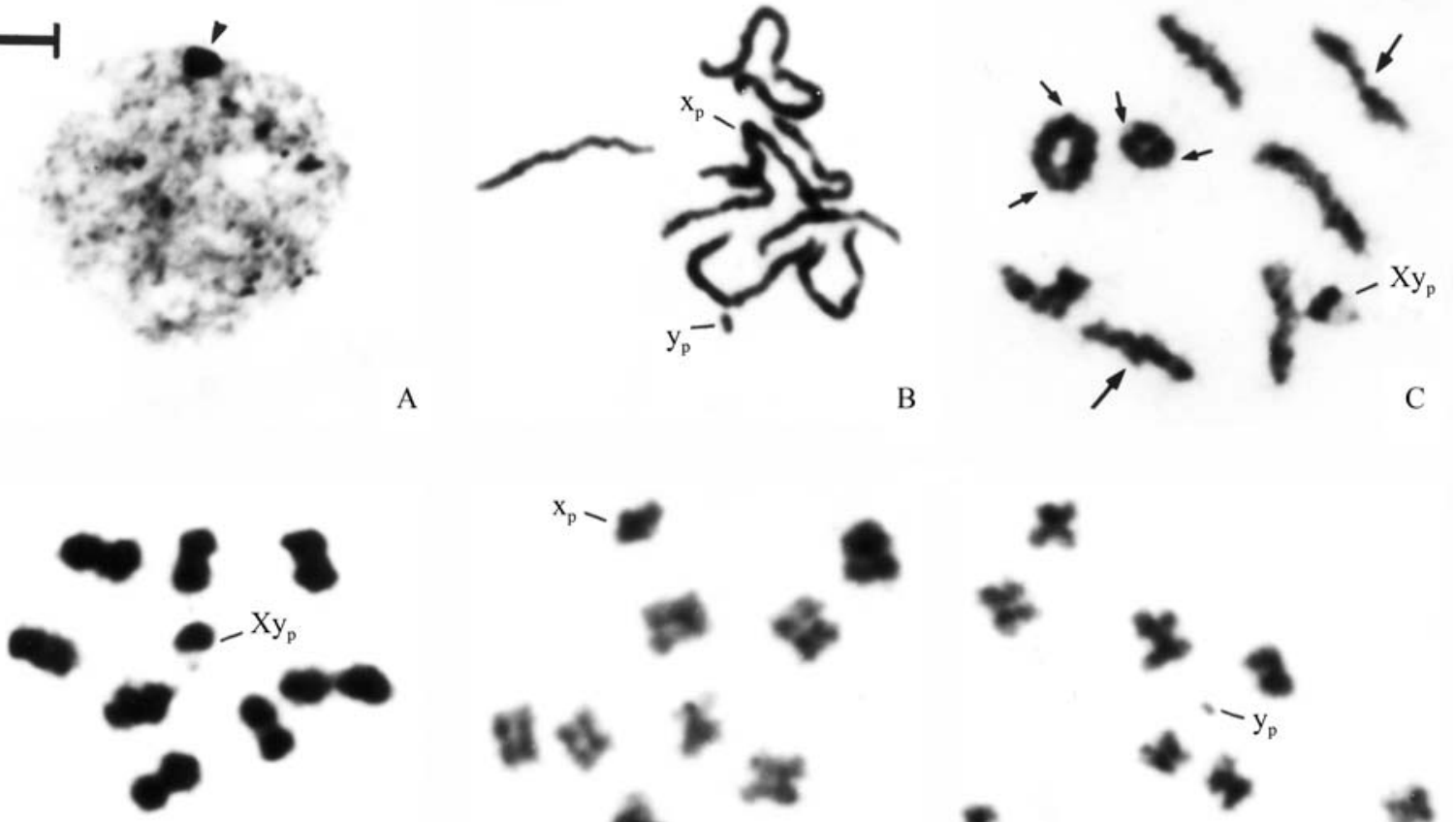

D
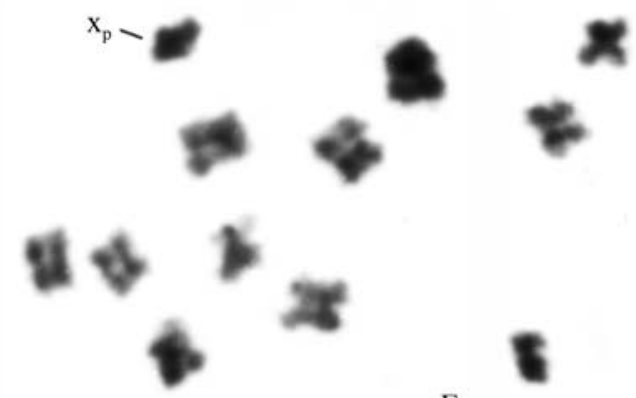

E

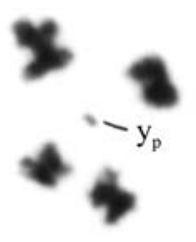

Figure 2 - Spermatocytes of Astylus variegatus: A) Interphase, with a prominent heteropycnotic block (arrowhead); B) Pachytene, with eight synapsed autosomal bivalents and two unpaired sex chromosomes; C-D) Diplotene and metaphase I, respectively, with $2 \mathrm{n}=8 \mathrm{II}+\mathrm{Xy}$ and sex chromosomes in a parachute configuration. In C, note the presence of one (large arrow) or two (small arrow) terminal chiasmata in the bivalents; E-F) Metaphase II cells, with $\mathrm{n}=8+X_{\mathrm{p}}$ and $\mathrm{n}=8+\mathrm{y}_{\mathrm{p}}$, respectively. Scale bar $=5 \mu \mathrm{m}$. 


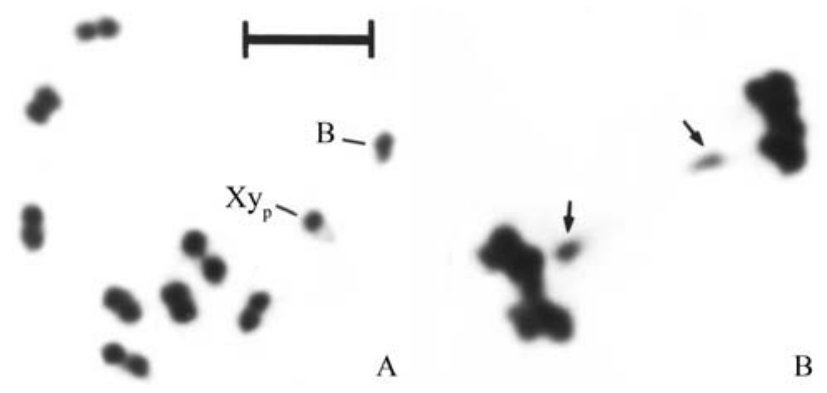

Figure 3 - Testes cells of Astylus variegatus: A) Metaphase I, $2 \mathrm{n}=8 \mathrm{II}+\mathrm{Xy} \mathrm{y}_{\mathrm{p}}+\mathrm{B}$; B) Anaphase, with late chromosome segregation (arrow). $\mathrm{B}=$ supernumerary chromosome. Scale bar $=5 \mu \mathrm{m}$.

\section{C-banding}

After C-banding of spermatogonial metaphases of $A$. variegatus, small and well-defined dots of constitutive heterochromatin were evidenced in the pericentromeric region of all chromosomes, with the exception of the $\mathrm{y}_{\mathrm{p}}$ (Figure 4B).

\section{Silver staining}

After Ag-NORs staining, testicular mitotic cells of $A$. variegatus presented tenuous and small NORs on the terminal region of the short arm of pair 2 (Figure 5A). In pachytene spermatocytes, nucleolar material was associated to one autosomal bivalent, in agreement with the spermatogonial cells results (Figure 5B-C). During metaphase I,

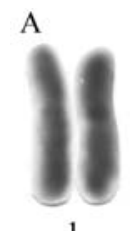

1

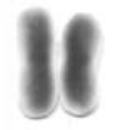

6

B

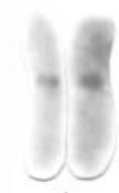

1

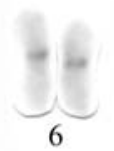

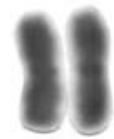

2

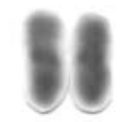

7

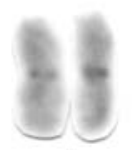

2

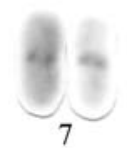

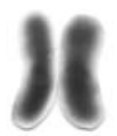

3

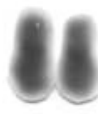

8

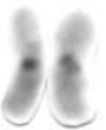

3

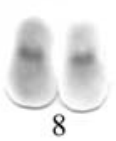

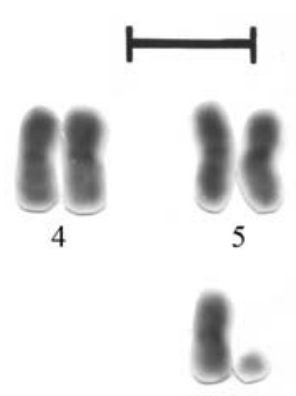

Xp yp
,

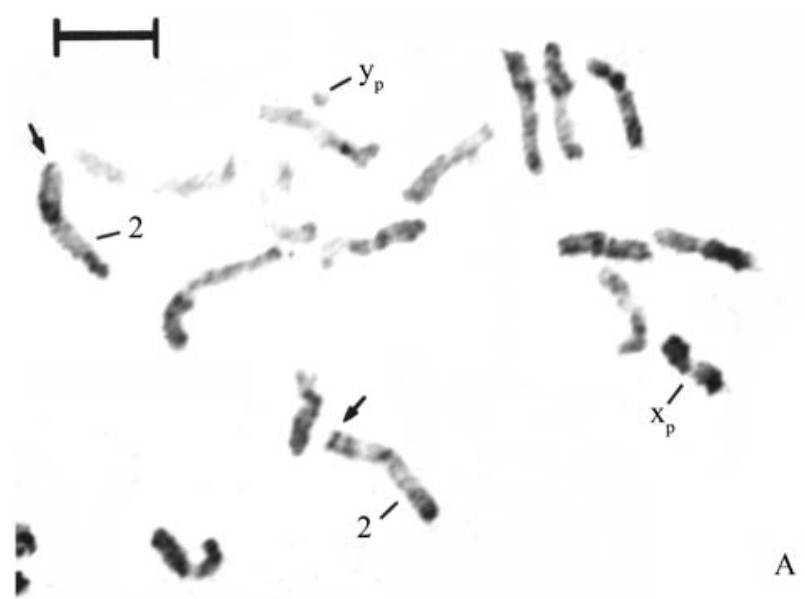

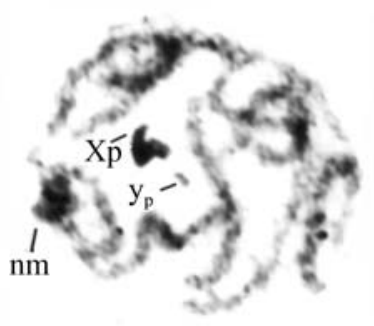

B
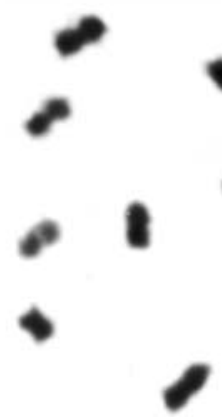

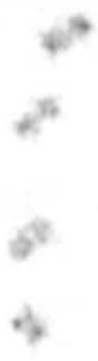

D
C

E
Figure 5 - Testes cells of Astylus variegatus after silver staining (A, C, and E) and Giemsa staining (B and D). A) Mitotic metaphase, $2 n=16+X y_{p}$, with one Ag-NOR on the short arm of the second pair (arrow). B-C) Pachytene, $2 \mathrm{n}=8 \mathrm{II}+\mathrm{Xy} \mathrm{y}_{\mathrm{p}}$, with nucleolar material $(\mathrm{nm})$ on one autosomal bivalent. D-E) Metaphase I, $2 \mathrm{n}=8 \mathrm{II}+\mathrm{Xyp}$, with an argentophilic block between the sex chromosomes (arrow). Scale bar $=5 \mu \mathrm{m}$.

only an argentophilic block between the sex chromosomes was observed (Figure 5D-E).

\section{Discussion}

Some cytogenetic features of $A$. variegatus herein described, such as the $\mathrm{Xy}_{\mathrm{p}}$ sex chromosome system and the metacentric chromosome morphology, are similar to those considered ancestral for beetles of the suborder Polyphaga. Nevertheless, the $2 \mathrm{n}=18$ of $A$. variegatus differs from the $2 \mathrm{n}=20$ proposed as basic for Polyphaga by Smith and Virkki (1978). The reduction of one autosome pair and the conservation of the metacentric morphology verified in the karyotype of $A$. variegatus probably results from a centric fusion between autosomes, which was preceded by fission

Figure 4 - Spermatogonial karyotypes of Astylus variegatus after Giemsa staining (A) and C-banding (B). The cells have $2 n=16+X y_{p}$ and constitutive heterochromatin in the pericentromeric region of all chromosomes, except for the $\mathrm{y}_{\mathrm{p}}$. Scale bar $=5 \mu \mathrm{m}$. 
and loss of entirely heterochromatic autosomal arms or, alternatively, by pericentric inversions.

Chromosome evolution involving diploid number reduction is evident not only in A. variegatus, but also in all previously studied species of the superfamily Cleroidea (Smith and Virkki, 1978; Yadav and Dange, 1989). The karyotype with $2 \mathrm{n}=16+X \mathrm{y}_{\mathrm{p}}$ of $A$. variegatus is shared with all 12 related species of the family Cleridae, but it is the first time that it is reported among Melyridae. Only four Melyridae species have already been cytogenetically analyzed (Smith and Virkki, 1978; present work) and the data reported for this family $(2 \mathrm{n}=18+\mathrm{X} 0 ; 2 \mathrm{n}=16+\mathrm{X} 0$; $\left.2 \mathrm{n}=16+X y_{\mathrm{p}} ; 2 \mathrm{n}=12+\mathrm{Xy}_{\mathrm{p}}\right)$ indicate that the chromosome variation can occur through the loss of the $\mathrm{y}_{\mathrm{p}}$, giving rise to the X0 sex chromosome system, and/or through autosomes fusions, reducing the chromosome number.

The study of meiotic cells of $A$. variegatus allowed observing that all chromosomes showed regular patterns of heteropycnosis, synapsis, orientation, and segregation. Nevertheless, some peculiarities regarding the number of chiasmata and the association of the $\mathrm{Xy}_{\mathrm{p}}$ sex bivalent were detected in this species. The occurrence of bivalents with two chiasmata, such as verified in A. variegatus, has occasionally been described in coleopterans (Smith and Virkki, 1978). In species of Cleroidea, it was only reported in Enoclerus sp. and Necrobia ruficolis (Virkki, 1963; Yadav and Dange, 1989). In Coleoptera, biquiasmatic bivalents seem to be more frequent in species which present chromosome differentiation through fusions, such as representatives of the family Elateridae (Smith, 1956a; Agarwal, 1962; Kacker, 1963; Ferreira et al., 1984; Yadav and Vyas, 1994). The presence of two chiasmata in these bivalents may be explained by the fact that the number of chiasmata partly depends on the chromosome length, as postulated by John (1990).

The parachute configuration of the $\mathrm{Xy}_{\mathrm{p}}$ bivalent during meiosis has been found in the great majority of beetle species of the Polyphaga suborder (Smith and Virkki, 1978 ) and it may result from a biquiasmatic association between the sex chromosomes (Smith, 1951), terminal heterochromatic non-specific association (Drets et al., 1983), or presence of nucleolar material on the sexual bivalent (John and Lewis, 1960). Contrarily to the proposal of Smith (1951), the $\mathrm{Xy}_{\mathrm{p}}$ pairing in A. variegatus was certainly aquiasmatic as the sex chromosomes were univalent elements during pachytene. C-banding revealed that the $X_{p}$ of A. variegatus only had pericentromeric heterochromatin and the $\mathrm{y}_{\mathrm{p}}$ was entirely C-band negative. Thus, the $\mathrm{Xy}_{\mathrm{p}}$ association in $A$. variegatus probably did not occur through the pairing of constitutive heterochromatic segments, as postulated by Drets et al. (1983) for Epilachna paenulata. The use of other methodologies to detect heterochromatin, such as the staining with base-specific fluorochromes, can be useful to confirm this hypothesis. On the other hand, the $\mathrm{Xy}_{\mathrm{p}}$ parachute configuration and the concomitant presence of an argentophilous material between these chromosomes in late prophase I and metaphase I cells suggests that the sex chromosomes association is related to the presence of this argentophilous material.

B chromosomes have already been described in approximately 50 Coleoptera species and subspecies (Smith and Virkki, 1978), belonging to some families, such as Chrysomelidae, Coccinellidae, and Lampyridae (Smith and Virkki, 1978; Nokkala and Nokkala, 1989; Maffei et al., 2000; Schneider et al., 2002). Nevertheless, this is the first time that B chromosomes are recorded for a representative of the superfamily Cleroidea. Smith (1956b) verified an increase in the frequency of supernumerary chromosomes in one population of Diabrotica undecimpunctata howardi (Coleoptera, Chrysomelidae) exposed to insecticides and suggested that a higher number of supernumeraries could provide advantageous effects to specimens from that population. A detailed investigation of the $\mathrm{B}$ chromosome synaptic behavior in A. variegatus may shed light on its origin, as it may share homology with some A chromosome. An analysis of the meiotic behavior of the $\mathrm{B}$ chromosome in $A$. variegatus may also help in elucidating how it accumulates and what causes its interpopulational frequency difference.

C-banding and Ag-NOR were very useful in establishing $\mathrm{Xy}_{\mathrm{p}}$ pairing during meiosis and in obtaining data on specific chromosome regions in a Melyridae species. The pericentromeric constitutive heterochromatin pattern observed in A. variegatus is similar to that reported for most polyphagan species (Almeida et al., 2000; Rozek et al., 2004). Moreover, chromosomes with small amounts of constitutive heterochromatin were observed in many coleopteran families, e.g. Anthicidae, Attelabidae, Cerambycidae, Chrysomelidae, and Curculionidae (Rozek et al., 2004). Most beetles of the suborders Adephaga and Polyphaga have NORs restricted to the autosomes, which were described in $81 \%$ of the species studied (Schneider et al., in press). In many species with the $\mathrm{Xy}_{\mathrm{p}}$ sex chromosome system, an argentophilous material, usually interpreted as nucleolar, has been frequently detected during meiosis (Virkki et al., 1990; Juan et al., 1993), as was the case in $A$. variegatus herein studied. According to Juan et al. (1993), the rDNA genes in these species may be exclusively located on autosomes and the product of the active autosomal NORs may be imported by the sex bivalent, where it could have a role in the association and disjunction of these chromosomes during meiosis. Ag-NORs were not observed in the sex chromosomes in mitotic cells of $A$. variegatus. It is thus possible that there is only an autosomal NOR, a hypothesis that could be confirmed by fluorescent in situ hybridization with an rDNA probe.

The comparison between individuals of the two $A$. variegatus populations revealed that, in addition to the difference in B chromosome frequency, these populations differ in the number of hypoploid cells. Although the aneuploidies could result from some experimental problem, the number of hypoploid cells was higher in the population exposed to agrochemical products and the chi-square test showed a statistically significant difference between both $A$. variegatus populations. Therefore, the aneuploidy may re- 
sult from the use of agrochemical products, which may interfere with spindle fiber polymerization. This, in turn, could trigger alterations in the chromosome distribution during cell division leading to aneuploidies (Rabello-Gay et al., 1991). It is worth to point out that the agrochemicals used in the Fazenda Escola Capão da Onça are non-specific for $A$. variegatus, which is frequently controlled with carbofuran. In conclusion, the high number of hypoploid gonadal cells in $A$. variegatus may reduce the number of viable gametes, leading to a decline in the population of the agricultural area. The use of agrochemical products may also be harmful to other ecologically important invertebrates.

\section{Acknowledgments}

The authors are grateful to Silvia D. Schneider for collecting some $A$. variegatus specimens and to Carlos Campaner, Museu de Zoologia, USP, São Paulo, SP, Brazil, for the identification of the specimens.

\section{References}

Agarwal U (1962) Studies on the structure and behavior of the chromosomes of five species of Indian Coleoptera. Jpn J Genet 37:57-65.

Almeida MC, Zacaro AA and Cella DM (2000) Cytogenetic analysis of Epicauta atomaria (Meloidae) and Palembus dermestoides (Tenebrionidae) with $\mathrm{X}_{\mathrm{p}}$ sex chromosome system using standard staining, C-bands, NOR and synaptonemal complex microspreading techniques. Hereditas 133:147-157.

Costa C (2003) Estado de conocimiento de los Coleoptera neotropicales. Bol SEA (Versión Eletronica 32). http://www. sea-entomologia.org/aracnet/11/01/index.htm.

Drets ME, Corbella E, Panzera F and Folle GA (1983) C-banding and non-homologous associations. II. The "parachute" Xyp sex bivalent and the behavior of heterochromatic segments in Epilachna paenulata. Chromosoma 88:249-255.

Ferreira A, Cella DM, Tardivo JR and Virkki N (1984) Two pairs of chromosomes: A new low record for Coleoptera. Rev Bras Genet 7:231-239.

Howell WM and Black DA (1980) Controlled silver staining of nucleolus organizer regions with protective colloidal developer: A 1-step method. Experientia 36:1014-1015.

John B (1990) Meiosis. Melbourn: Cambridge University Press, Cambridge, 396 pp.

John B and Lewis KR (1960) Nucleolar controlled segregation of the sex chromosomes in beetles. Heredity 15:431-439.

Juan C, Pons J and Petitpierre E (1993) Localization of tandemly repeated DNA sequences in beetle chromosomes by fluorescent in situ hybridization. Chromosome Res 1:167-174.

Kacker RK (1963) Studies on the chromosomes of Indian Coleoptera. I. Meiosis in an elaterid beetle; Agrypnus sp. Nucleus 6:103-106.

Lawrence JF and Newton Jr AF (1995) Families and subfamilies of Coleoptera (with selected genera, notes, references and data on family-group names). In: Pakaluk J and Slipinski SA (eds). Biology, Phylogeny, and Classification of Coleoptera: Papers Celebrating the 80th Birthday of Roy A. Crowson. Muzeum i Instytut Zoologii, Warszawa pp 559-1092.
Levan A, Fredga K and Sandberg AA (1964) Nomenclature for centromeric position of chromosomes. Hereditas 52:201220.

Maffei EMD, Gasparino E and Pompolo SG (2000) Karyotypic characterization by mitosis, meiosis and C-banding of Eriopis connexa Mulsant (Coccinellidae, Coleoptera, Polyphaga), a predator of insect pests. Hereditas 132:79-85.

Matioli JC, Rossi MM and Carvalho CF (1990) Ocorrência e distribuição mensal de Astylus variegatus (Germar, 1824) e A. sexmaculatus (Perty, 1830) (Coleoptera, Dasytidae) em alguns municípios do estado de Minas Gerais. An Soc Ent Brasil 19:373-382 (Abstract in English).

Nokkala C and Nokkala S (1989) Characteristics of B-chromosomes in Galerucella nymphaeae species complex (Coleoptera, Chrysomelidae). Hereditas 111:175-181.

Rabello-Gay MN, Rodrigues MAR and Monteleon-Neto R (1991) Mutagênese, teratogênese e carcinogênese: Métodos e critérios de avaliação. Sociedade Brasileira de Genética, Ribeirão Preto, 246 pp.

Rozek M, Lachowska D, Petitpierre E and Holecová M (2004) C-bands on chromosomes of 32 beetle species (Coleoptera, Elateridae, Cantharidae, Oedemeridae, Cerambycidae, Anthicidae, Chrysomelidae, Attelabidae and Curculionidae). Hereditas 140:161-170.

Schneider MC, Artoni RF and Almeida MC (2002) Cytogenetic analysis of 3 populations of Diabrotica speciosa (Chrysomelidae, Galerucinae): Constitutive heterochromatin and nucleolus organizer regions. Cytologia 67:281-287.

Schneider MC, Rosa SP, Almeida MC, Costa C and Cella DM (in press) Chromosomal similarities and differences among four Neotropical Elateridae (Conoderini and Pyrophorini) and other related species, with comments on the NOR patterns in Coleoptera. J Zoolog Syst Evol Res.

Smith SG (1951) Evolutionary changes in the sex chromosomes of Coleoptera. Genetica 25:522-524.

Smith SG (1956a) Spermatogenesis in an elaterid beetle. J Hered 47:2-10.

Smith SG (1956b) The status of supernumerary chromosomes in Diabrotica. J Hered 47:157-164.

Smith SG and Virkki N (1978) Animal Cytogenetics. v. 3, Insecta 5. Coleoptera. Gebrüder Borntraeger, Berlin, 366 pp.

Stevens NM (1906) Studies in spermatogenesis II. Carneg Inst Wash 36:33-74.

Sumner AT (1972) A simple technique for demonstrating centromeric heterochromatin. Exp Cell Res 75:304-306.

Vianna PA, Cruz I and Waquil JM (2002) Cultivo do milho: Pragas iniciais. Comunicado Técnico - Ministério da Agricultura, Pecuária e Abastecimento. 59:1-13. http://www. cnpms.embrapa.br/publicacoes/publica/comuni59.pdf.

Virkki N (1960) Cytology of male meiosis in certain european forest beetles of the families Scolytidae, Cleridae, and Anobiidae. Ann Acad Sci Fenn A-IVB 49:1-18.

Virkki N (1963) On the cytology of some Neotropical Cantharoids (Coleoptera). Ann Acad Sci Fenn A-IVB 65:1-17.

Virkki N, Mazzella C, Denton A (1990) Staining of substances adjacent to the sex bivalent in certain weevils of Puerto Rico. J Agric Univ P R 74:405-418.

Yadav JS and Dange MP (1989) On the cytology of two species of Necrobia (Oliv.) (Coleoptera, Cleridae). Genome 32:165-167.

Yadav JS and Vyas S (1994) Karyotypes and meiosis in four species of Pyrophorinae (Elateridae, Coleoptera). Cell Chromosome Res 17:27-34.

Associate Editor: Catarina S. Takahashi 